DOI 10.22460/jpmi.v1i3.325-332

\title{
ANALISIS KEMAMPUAN BERPIKIR KRITIS MATEMATIS BERDASARKAN MOTIVASI BELAJAR MATEMATIS SISWA SMP
}

\author{
Neneng Yunita ${ }^{1}$, Tina Rosyana ${ }^{2}$, Heris Hendriana ${ }^{3}$ \\ 1,2,3 IKIP Siliwangi, Jl. Terusan Jenderal Sudirman, Cimahi, Jawa Barat, Indonesia \\ ${ }^{1}$ nenegyunita96@gmail.com, ${ }^{2}$ tinarosyana@gmail.com, ${ }^{3}$ hendriana@ stkipsiliwangi.ac.id
}

Diterima: 20 Maret 2018; Disetujui: 28 Mei 2018

\begin{abstract}
This study aims to determine the ability to think critically mathematically based on the motivation of junior high school students. The method in this research using correlational method with quantitative approach. The population in this study is in one of the junior high schools in western Bandung and the number of samples as many as 29 students with heterogeneous ability. Intrumen in this research is in the form of test of critical thinking ability capability with number of seven item and non test in the form of learning motivation scale which consist of 25 scale statement. The results of this study obtained that the ability to think critically mathematically based on learning motivation has a positive effect of $16.2 \%$. While $83.8 \%$ influenced in addition to student learning motivation.
\end{abstract}

Keywords: Mathematical Critical Thinking, Motivation to Learn

\begin{abstract}
Abstrak
Penelitian ini bertujuan untuk mengetahui kemampuan berpikir kritis matematis berdasarkan motivasi belajar siswa SMP. Metode dalam penelitian ini menggunakan metode korelasional dengan pendekatan kuantitatif. Populasi dalam penelitian ini adalah di salah satu SMP di Bandung barat dan jumlah sampelnya sebanyak 29 siswa dengan kemampuan heterogen. Intrumen dalam penelitian ini adalah berbentuk tes uraian kemampuan berpikir kritis dengan jumlah tujuh butir soal dan non tes berupa skala motivasi belajar yang terdiri dari 25 skala pernyataan. Hasil penelitian ini memperoleh bahwa kemampuan berpikir kritis matematis berdasarkan motivasi belajar berpengaruh positif sebesar $16,2 \%$. Sedangkan 83,8 \% di pengaruhi selain dari motivasi belajar siswa.
\end{abstract}

Kata Kunci: Berpikir Kritis Matematis, Motivasi Belajar

How to cite: Yunita, N., Rosyana, T., \& Hendriana, H. (2018). Analisis Kemampuan Berpikir Kritis Matematis berdasarkan Motivasi Belajar Matematis Siswa SMP. JPMI - Jurnal Pembelajaran Matematika Inovatif, 1 (3), 325-332.

\section{PENDAHULUAN}

Mencerdaskan kehidupan bangsa adalah tujuan bangsa Indonesia, salah satunya melalui pendidikan. Menurut \{Formatting Citation \} pendidikan merupakan usaha sadar dan terencana untuk mewujudkan suasana belajar dan proses pembelajaran agar peserta didik secara aktif mengembangkan potensi dirinya untuk memiliki kemampuan terhadap apa yang dipelajari. Pendidikan salah satunya dilaksanakan di sekolah, materi yang dipelajari diantaranya yaitu pelajaran matematika. Matematika pada dasarnya sebagai ratunya ilmu dan pelayan ilmu, matematika dapat dikatakan sebagai ratunya ilmu karena matematika berkaitan dengan segala bidang ilmu. 
Pembelajaran matematika di sekolah kebanyakannya siswa hanya memperhatikan saja dan guru yang berperan aktif, dalam pembelajarannya peserta didik jarang dilatih dengan soal-soal yang tidak rutin sehingga siswa tidak terbiasa. Hal tersebut dapat terlihat dari hasil yang dikemukakan oleh TIMSS 2015 (Widayanti, Suyono, \& Rahayu, 2018) peserta didik Indonesia masih lemah dalam kecakapan kognitif tingkat tinggi seperti menalar, menganalisa, mengevaluasi sehingga kemampuan berpikir kritis peserta didik masih tergolong rendah; kemampuan awal dan kesiapan peserta didik indonesia untuk belajar sudah cukup baik namun masih berada di level rendah; persepsi peserta didik indonesia terhadap matematika besar, namun pada saat diminta menjawab soal-soal, kepercayaan diri terhadap kemampuan matematika yang dimilikinya masih tergolong rendah (Dilla, Hidayat, \& Rohaeti, 2018; Hendriana, Rohaeti, \& Hidayat, 2017; Hendriana, Hidayat, \& Ristiana, 2018; Hidayat, 2011; 2012; Rahmi, Nadia, Hasibah, \& Hidayat, 2017; Sumarmo, Hidayat, Zukarnaen, Hamidah, \& Sariningsih, 2012; Sumarmo, Mulyani, \& Hidayat, 2018; Tresnawati, Hidayat, \& Rohaeti, 2017).

Kemampuan berpikir pada setiap siswa perlu dilatih salah satunya pada kemampuan berpikir kritis. Menurut Wijaya (Istianah, 2013)menyatakan bahwa berpikir kritis mengarah pada kegiatan menganalisa gagasan ke arah yang lebih spesifik, membedakan sesatu hal secara tajam, memilih, mengidentifikasi, mengkaji dan mengembangkan ke arah yang lebih sempurna. Menurut Silverman dan Smith (Naafidza \& Budiarto, 2014) berpikir kritis merupakan berpikir yang mempunyai maksud, masuk akal dan berorientasi tujuan dan kecakapan untuk menganalisis sesuatu informasi dan ide secara hati-hati dan logis. Sedangkan menurut Ennis (Hendriana, Rohaeti, \& Sumarmo, 2017) mendefinisikan berpikir kritis sebagai berpikir reflektif yang beralasan dan difokuskan pada penetapan apa yang dipercayai atau yang dilakukan. Berpikir kritis berelasi dengan lima ide kunci yaitu praktis, reflektif, masuk akal, kepercayaan dan aksi. Terdapat lima Indikator kemampuan berpikir kritis menurut (Sumarmo, 2016) diantaranya yaitu a) memeriksa kebenaran argumen, pernyataan dan proses solusi, b) menyusun pertanyaan disertai alasan, c) mengidentifikasi data relevan dan tidak relevan suatu masalah matematika, d) mengidentifikasi asumsi, dan e) menyusun jawaban/menyelesaiakn masalah matematika disertai alasan.

Motivasi belajar dapat muncul ketika siswa ingin mencapai tujuan, seperti yang dikemukakan definisi motivasi oleh Mc.Donald (Hendriana et al., 2017) bahwa motivasi adalah perubahan energi dalam diri seseorang yang ditandai dengan munculnya "feeling" dan didahului dengan tanggapan terhadap adanya tujuan. dalam mengembangkan kemampuan berpikir kritis siswa salah satunya dapat dilihat dari sejauh mana motivasi belajar peserta didik dalam mencapai tujuan tersebut. Sehingga motivasi belajar dapat mempengaruhi kemampuan berpikir kritis siswa.

Berdasarkan paparan diatas, diperlukan penelitian pada kemampuan berpikir kritis matematis berdasarkan motivasi belajar siswa SMP. Rumusan masalah dalam penelitian ini bagaimana kemampuan berpikir kritis matematis berdasarkan motivasi belajar siswa SMP, dan tujuan dalam penelitian ini adalah untuk mengetahui kemampuan berpikir kritis matematis berdasarkan motivasi belajar siswa SMP.metode

Bagian Metode harus singkat, namun harus mencakup informasi teknis yang memadai agar penelitian dapat dilanjutkan oleh pembaca yang berkompeten. Untuk metode baru harus dijelaskan secara rinci. Mengutip prosedur yang telah diterbitkan sebelumnya dalam referensi. 


\section{METODE}

Metode dalam penelitian ini menggunakan metode korelasional dengan pendekatan kuantitatif yang bertujuan untuk mengetahui dengan menganalisis kemampuan berpikir kritis matematis berdasarkan motivasi belajar siswa SMP. Populasi dalam penelitian ini adalah siswa SMP di Kabupaten Bandung Barat. Sedangkan sampelnya sebanyak 29 siswa dengan kemampuan heterogen. Instrumen dalam penelitian ini menggunakan soal tes kemampuan berpikir kritis matematis bentuk uraian yang terdiri dari tujuh butir soal dan non tesnya berupa skala motivasi belajar yang terdiri dari 25 pernyataan. Data hasil penelitian diolah dan dianalisis menggunakan uji statistika regresi. Hanya saja sebelum dilakukan uji statistika regregi dilakukan uji normalitas dan uji linearitas terlebih dahulu.

Berikut ini disajikan contoh butir tes uraian kemampuan berpikir kritis matematis, dan non tes skala motivasi belajar pada Gambar 1 dan Gambar 2.

1. Sebuah persegi panjang memiliki luas $108 \mathrm{~cm}^{2}$ dengan panjang $9 \mathrm{~cm}$, lebar $12 \mathrm{~cm}$ dan diagonal panjangnya $15 \mathrm{~cm}$. Benarkah pernyataan diatas? Jelaskan!

2. Perhatikan gambar dibawah ini!
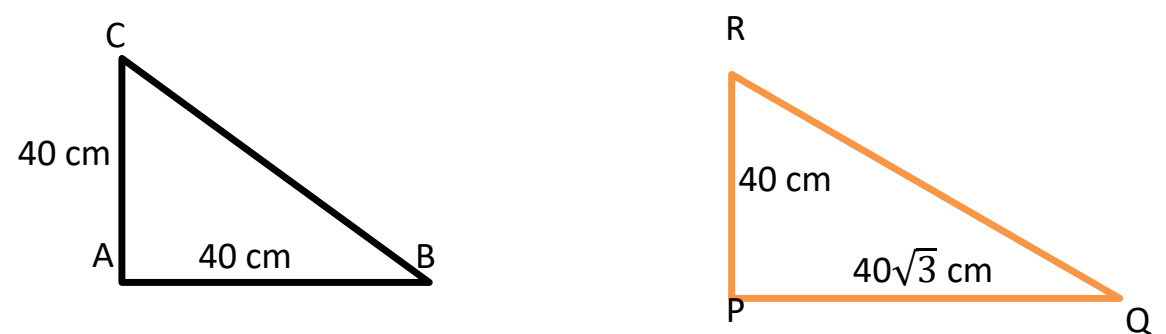

Terdapat dua buah segitiga yaitu $\triangle A B C$ dan $\triangle \mathrm{PQR}$. Panjang $\mathrm{AB}=\mathrm{AC}$ dan panjang $\mathrm{PQ}=$ $40 \sqrt{3} \mathrm{~cm}, \mathrm{PR}=40 \mathrm{~cm}$. Apakah panjang $\mathrm{BC}=\mathrm{QR}$ ? Jelaskan!

Gambar 1. Intrumen tes uraian kemampuan berpikir kritis matematis siswa

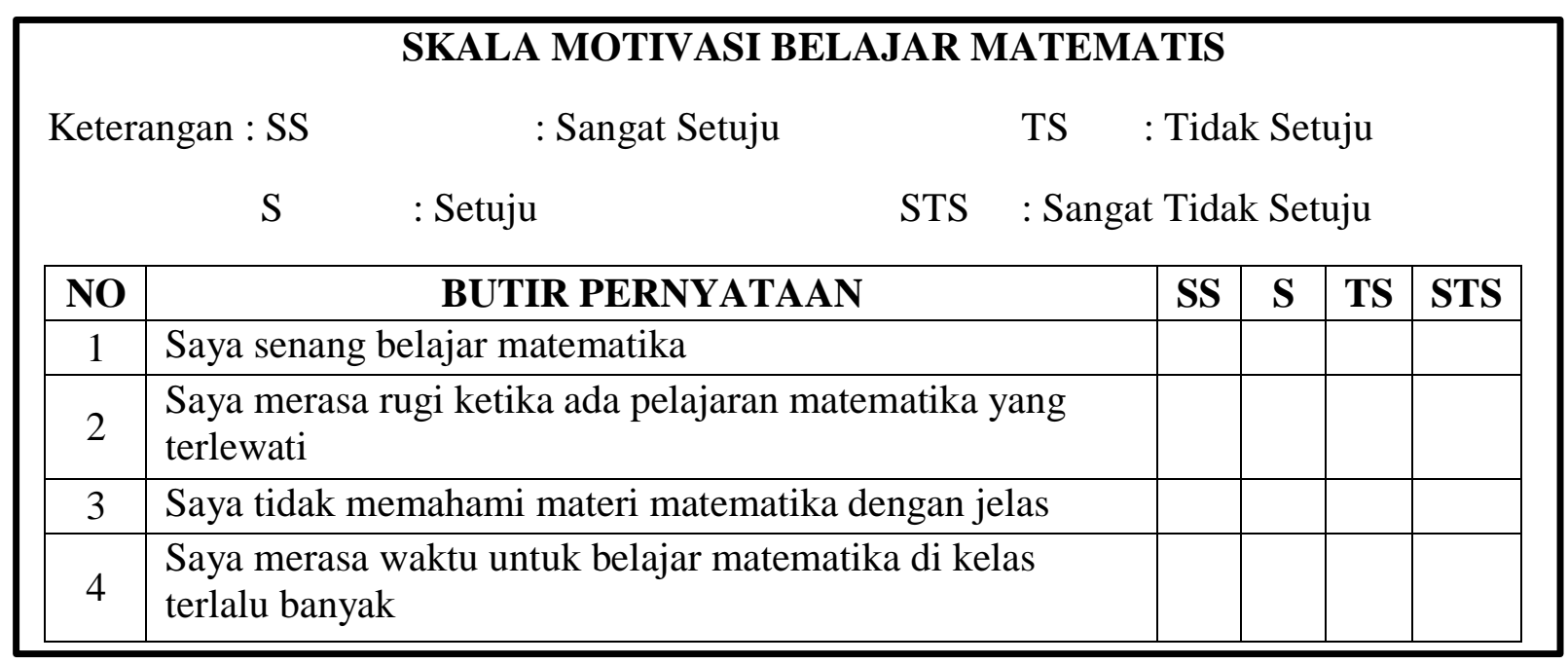

Gambar 2. Intrumen nontes skala motivasi belajar matematis siswa 


\section{HASIL DAN PEMBAHASAN}

\section{Hasil}

Data yang diperoleh dari hasil ujicoba instrumen telah dianalisis bahwa kemampuan berpikir kritis matematis dan motivasi belajar matematis siswa berdistribusi normal. Selanjutnya dilakukan uji linearilitas kemampuan berpikir kritis matematis dan motivasi belajar matematis siswa dengan hasil pengujian pada Tabel 1 dibawah ini.

Tabel 1. Uji Linearitas Kemampuan Berpikir Kritis Matematis Berdasarkan Motivasi Belajar

\begin{tabular}{|c|c|c|c|c|c|c|c|}
\hline & & & $\begin{array}{l}\text { Sum } \\
\text { Squares }\end{array}$ & df & $\begin{array}{l}\text { Mean } \\
\text { Square }\end{array}$ & $\mathbf{F}$ & Sig. \\
\hline \multirow{5}{*}{$\begin{array}{l}\text { kemampuan } \\
\text { berpikir kritis * } \\
\text { motivasi belajar }\end{array}$} & \multirow{3}{*}{$\begin{array}{l}\text { Between } \\
\text { Groups }\end{array}$} & (Combined) & 674,810 & 22 & 30,673 & 1,990 & 0,200 \\
\hline & & Linearity & 124,062 & 1 & 124,062 & 8,047 & 0,030 \\
\hline & & $\begin{array}{l}\text { Deviation from } \\
\text { Linearity }\end{array}$ & 550,749 & 21 & 26,226 & 1,701 & 0,264 \\
\hline & \multicolumn{2}{|c|}{ Within Groups } & 92,500 & 6 & 15,417 & & \\
\hline & \multicolumn{2}{|l|}{ Total } & 767,310 & 28 & & & \\
\hline
\end{tabular}

Berdasarkan hasil uji linearitas kemampuan berpikir kritis matematis dan motivasi belajar siswa, dapat dilihat dari nilai Sig. pada Deviation from linearity sebesar 0,264. Jika (Sig. $>\alpha$ $=0.05$ ) yang mengakibatkan bahwa kemampuan berpikir kritis matematis dan motivasi belajar siswa terdapat hubungan yang linear.

Selajutnya, dilakukan statistika regresi untuk melihat apakah terdapat pengaruh pada kemampuan berpikir kritis matematis berdasarkan motivasi belajar siswa. dibawah ini merupakan hasil pengujian regresi yang disajikan pada Tabel 2.

Tabel 2. Uji Regresi Kemampuan Berpikir Kritis dan Motivasi Belajar siswa

\begin{tabular}{llccccc}
\hline & Model & $\begin{array}{c}\text { Sum of } \\
\text { Squares }\end{array}$ & Df & Mean Square & F & Sig. \\
\hline 1 & Regression & 124,062 & 1 & 124,062 & 5,207 & $0,031^{\text {b }}$ \\
\cline { 2 - 7 } & Residual & 643,249 & 27 & 23,824 & & \\
\cline { 2 - 4 } & 767,310 & 28 & & & \\
\hline
\end{tabular}

Berdasarkan hasil uji regresi pada Tabel 2 dapat terlihat bahwa nilai Sig. Regression sebesar 0,031. Jika (Sig. $<\alpha=0.05$ ) yang mengakibatkan bahwa terdapat pengaruh positif antara kemampuan berpikir kritis dan motivasi belajar. 
Tabel 3. Model Summary

\begin{tabular}{ccccc}
\hline Model & R & R Square & Adjusted R Square & Std. Error of the Estimate \\
\hline 1 & $0,402^{\mathrm{a}}$ & 0,162 & 0,131 & 4,881 \\
\hline
\end{tabular}

Berdasarkan Tabel 3 dapat terlihat koefisien korelasi pada kolom R sebesar 0,402. Dan nilai koefisien determinasi pada kolom $R$ Square sebesar 0,162. Hal ini dapat diartikan bahwa kemampuan berpikir kritis matematis siswa berdasarkan motivasi berlajar berpengaruh sebesar $16,2 \%$.

Tabel 4. Koefisien Regresi

\begin{tabular}{|c|c|c|c|c|c|c|}
\hline & \multirow[b]{2}{*}{ Model } & \multicolumn{2}{|c|}{$\begin{array}{l}\text { Unstandardized } \\
\text { Coefficients }\end{array}$} & \multirow{2}{*}{$\begin{array}{c}\text { Standardized } \\
\text { Coefficients } \\
\text { Beta }\end{array}$} & \multirow[b]{2}{*}{$\mathbf{t}$} & \multirow[b]{2}{*}{ Sig. } \\
\hline & & B & Std. Error & & & \\
\hline \multirow[t]{2}{*}{1} & (Constant) & 69,923 & 2,500 & & 27,964 & 0,000 \\
\hline & $\begin{array}{l}\text { motivasi } \\
\text { belajar }\end{array}$ & 0,141 & 0,062 & 0,402 & 2,282 & 0,031 \\
\hline
\end{tabular}

Berdasarkan Tabel 4 dapat dilihat pada kolom B mengenai persamaan regresinya pada kemampuan berpikir kritis matematis berdasarkan motivasi belajar sebagai berikut:

$Y=69,923+0,141 x$

Dari persamaan berikut dapat terlihat bahwa motivasi belajar siswa berpengaruh positif dengan ditunjukan hasilnya sebesar 0,141 . Serta kemampuan berpikir kritis siswa mencapai 69,923. Sehingga dapat disimpulkan kemampuan berpikir kritis matematis berdasarkan motivasi siswa berpengaruhnya kecil.

\section{Pembahasan}

Dari hasil analisis data hasil penelitian terlihat bahwa terdapat pengaruh yang positif pada kemampuan berpikir kritis matematis pada motivasi belajar siswa, pengaruh yang positif tersebut dapat dilihat dari motivasi siswa dalam menyelesaikan soal uraian kemampuan berpikir kritis matematis. Siswa yang motivasi belajarnya tinggi dalam pelajaran matematika siswa tersebut dapat menyelesaian soal uraian kemampuan berpikir kritis matematis dengan baik, sedangkan siswa yang motivasi belajarnya kurang dalam pelajaran matematika cenderung menyelesaikannya sesuai pemahaman yang siswa miliki. Skor maksimal dalam tes kemampuan berpikir kritis matematis pada penelitian ini adalah 61, siswa yang mendapatkan nilai tertinggi dalam tes kemampuan berpikir kritis matematis berdasarkan motivasi belajar diambil dari empat teratas, yaitu diantaranya kode siswa S-10, kode siswa S-20, kode siswa S22, dan kode siswa S-29. Sedangkan siswa yang mendapatkan nilai terendah dalam tes kemampuan berpikir kritis matematis berdasarkan motivasi belajar diambil dari empat terbawah, yaitu diantaranya kode siswa S-1, kode siswa S-13, kode siswa S-2, dan kode siswa S-14. 
Hasil penelitian menunjukkan bahwa kode siswa S-10, kode siswa S-20, kode siswa S-22, dan kode siswa S-29 mendapatkan hasil tes tertinggi berdasarkan motivasi belajar siswa. Keempat siswa tersebut mampu memeriksa kebenaran argumen, mampu menyusun pertanyaan disertai alasan, mampu mengidentifikasi data relevan dan tidak relevan suatu masalah dalam matematika, mampu mengidentifikasi asumsi, dan mampu menyusun jawaban/menyelesaikan masalah matematika. Dengan demikian, kode siswa S-10, kode siswa S-20, kode siswa S-22, dan kode siswa S-29 sudah memenuhi semua indikator dari masing-masing tahapan kemampuan berpikir kritis matematis. Jadi dapat dikatakan berdasarkan motivasi belajar keempat siswa tersebut memiliki kemampuan berpikir kritis matematis yang sangat baik dalam menelaah permasalahan hingga mencari penyelesaian yang tepat.. Hal tersebut sesuai dengan yang dikemukakan oleh kurniasih \{Formatting Citation\}seseorang yang memiliki kemampuan berpikir kritis akan dapat menelaah permasalahan yang dihadapi, mencari dan memilih penyelesaian yang tepat, logis dan bermanfaat. Dan tingginya motivasi belajar dari keempat siswa terlihat dalam mengambil keputusan untuk menjawab pertanyaan pada tes kemampuan berpikir kritis matematis. Sesuai dengan penelitian (Sulistianinsih, 2016) menyatakan bahwa motivasi yang tinggi terlihat dari kapasitas dalam belajar, mengambil resiko, menjawab pertanyaan serta kesediaan untuk bertanggung jawab. Hasil dari empat siswa yang memiliki nilai tertinggi dalam tes kemampuan berpikir kritis matematis berdasarkan motivasi belajar dapat dilihat pada Tabel 5 .

Tabel 5. Nilai Tertinggi Siswa Pada Tes Kemampuan Berpikir Kritis Matematis Berdasarkan Motivasi Belajar

\begin{tabular}{lll}
\hline NO & KODE SISWA & TOTAL SKOR \\
\hline 1 & S-10 & 58 \\
2 & S-20 & 55 \\
3 & S-22 & 54 \\
4 & S-29 & 43 \\
Rata-rata & & 52,5 \\
\hline
\end{tabular}

Hasil penelitian menunjukkan bahwa kode siswa S-1, kode siswa S-13, kode siswa S-2, dan kode siswa S-14 yang mendapatkan nilai terendah dalam tes kemampuan berpikir kritis matematis berdasarkan motivasi belajar diambil dari empat terbawah,.dari keempat siswa tersebut rata-rata belum mampu mengindentifikasi asumsi, belum mampu menyusun pertanyaan disertai alasan, dan belum mampu menyusun jawaban/menyelesaikan masalah matematika diserta alasan. Dengan demikian, kode siswa S-1, kode siswa S-13, kode siswa S2, dan kode siswa S-14 hanya memenuhi dua indikator saja yaitu mengidentifikasi data relevan dan tidak relevan suatu masalah dalam matematika serta memeriksa kebenaran argumen,pernyataan dan proses solusi. Jadi dapat dikatakan pada keempat siswa terbawah tersebut memiliki kemampuan berpikir kritis matematis berdasarkan motivasi belajarnya masih rendah. Hal tersebut dikarenakan keempat siswa terbawah dalam memahami dan cara menanggapi informasi pada soal tes kurang maksimal sehingga daya nalarnya kurang digunakan. Sesuai dengan penelitian yang dikemukakan oleh Tarigan (Nugroho, 2017) bahwa siswa kurang mampu menggunakan daya nalar dalam menanggapi informasi yang diterimanya. Hasil dari empat siswa yang memiliki nilai terrendah dalam tes kemampuan berpikir kritis matematis berdasarkan motivasi belajar dapat dilihat pada Tabel 6 . 
Tabel 6. Nilai Terrendah Siswa Pada Tes Kemampuan Berpikir Kritis Matematis Berdasarkan Motivasi Belajar

\section{NO KODE SISWA TOTAL SKOR}

\begin{tabular}{ccc}
\hline 1 & S-1 & 18 \\
2 & S-13 & 18 \\
3 & S-2 & 14 \\
4 & S-14 & 5 \\
\hline rata-rata & & 13,75 \\
\hline
\end{tabular}

\section{KESIMPULAN}

Berdasarkan hasil dan pembahasan yang telah disajikan, maka dapat disimpulkan bahwa kemampuan berpikir kritis matematis berdasarkan motivasi belajar pada siswa SMP memiliki pengaruh positif sebesar $16,2 \%$. Sedangkan $83,8 \%$ di pengaruhi selain dari motivasi belajar siswa.

\section{DAFTAR PUSTAKA}

Dilla, S. C., Hidayat, W., \& Rohaeti, E. E. (2018). Faktor Gender dan Resiliensi dalam Pencapaian Kemampuan Berpikir Kreatif Matematis Siswa SMA. Journal of Medives, 2(1), 129-136.

Hendriana, H., Rohaeti, E. E., \& Hidayat, W. (2017). Metaphorical Thinking Learning and Junior High School Teachers' Mathematical Questioning Ability. Journal on Mathematics Education, 8(1), 55-64.

Hendriana, H., Rohaeti, E.E, \& Sumarmo, U. (2017). Hard Skills dan Soft Skills Matematik Siswa (1st ed.). Bandung: Refika Aditama.

Hendriana, H., Hidayat, W., \& Ristiana, M. G. (2018, January). Student teachers' mathematical questioning and courage in metaphorical thinking learning. In Journal of Physics: Conference Series (Vol. 948, No. 1, p. 012019). IOP Publishing.

Hidayat, W. (2011). Meningkatkan Kemampuan Berpikir Kritis dan Kreatif Matematik Siswa Melalui Pembelajaran Kooperatif Think-Talk-Write (TTW) (Doctoral dissertation, Universitas Pendidikan Indonesia).

Hidayat, W. (2012). Meningkatkan Kemampuan Berpikir Kritis dan Kreatif Matematik Siswa SMA Melalui Pembelajaran Kooperatif Think-Talk-Write (TTW). In Seminar Nasional Penelitian, Pendidikan dan Penerapan MIPA.

Istianah, E. (2013). Meningkatkan Kemampuan Berpikir Kritis dan Kreatif Matematik dengan Pendekatan Model Eliciting Activities (Meas) pada Siswa SMA. Infinity, 2(1), 43-54. https://doi.org/https://doi.org/10.22460/infinity.v2i1.23

Marzuki, \& Tursina, D. (2017). Upaya Meningkatkan Prestasi Belajar Siswa Melalui Problem Based Learning pada Materi Penjumlahan dan Pengurangan Dua Bilangan Tiga Angka Tentang Soal Cerita Di Kelas III Negeri 27 Peusangan. Jurnal Pendidikan Dasar, 4(1), 
332 Yunita, Rosyana, \& Hendriana, Analisis Kemampuan Berpikir Kritis Matematis ...

43-48.

Naafidza, Z. Q. A., \& Budiarto, M. T. (2014). Identifikasi Kemampuan Berpikir Kritis Siswa SMP dalam Memecahkan Masalah Matematika Ditinjau dari Perbedaan Kemampuan Matematika dan Jenis Kelamin. Jurnal Ilmiah Pendidikan Matematika, 3(3), 97-102.

Nugroho, P. B. (2017). Scaffolding Meningkatkan Kemampuan Berpikir Kritis dalam Pembelajaran Matematika. Jurnal Silogisme, 2(1), 15-21.

Rahmi, S., Nadia, R., Hasibah, B., \& Hidayat, W. (2017). The Relation between Self-Efficacy toward Math with the Math Communication Competence. Infinity Journal, 6(2), 177182.

Sulistianinsih, P. (2016). Pengaruh Kecerdasan Emosional dan Motivasi Belajar terhadap Kemampuan Berpikir Kritis Matematika. JKPM, 02(01), 129-139.

Sumarmo, U. (2016). Pedoman Pemberian Skor Pada Beragam Tes Kemampuan Matematik, $1-19$. Retrieved from http://utarisumarmo.dosen.stkipsiliwangi.ac.id/files/2016/05/Pedoman-Pemberian-Skor-TesKemampuan-Berpikir-Matematik-dan-MPP-2016-1.pdf

Sumarmo, U., Hidayat, W., Zukarnaen, R., Hamidah, M., \& Sariningsih, R. (2012). Kemampuan dan Disposisi Berpikir Logis, Kritis, dan Kreatif Matematik (Eksperimen terhadap Siswa SMA Menggunakan Pembelajaran Berbasis Masalah dan Strategi Think-Talk-Write). Jurnal Pengajaran MIPA, 17(1), 17-33.

Sumarmo, U., Mulyani, E., \& Hidayat, W. (2018). Mathematical Communication Ability and Self Confidence Experiment with Eleventh Grade Students Using Scientific Approach. JIML-Journal of Innovative Mathematics Learning, 1(1), 19-30.

Tresnawati, T., Hidayat, W., \& Rohaeti, E. E. (2017). Kemampuan Berpikir Kritis Matematis dan Kepercayaan Diri Siswa SMA. Symmetry: Pasundan Journal of Research in Mathematics Learning and Education, 2(2), 39-45.

Widayanti, Suyono, \& Rahayu, W. (2018). Pengaruh Model Pembelajaran Berbasis Penemuan Kemampuan Berpikir Kritis Matematis dan Self Concept dengan Mengontrol Kemampuan Awal Peserta Didik Kelas VII SMP. JPPM, 11(1). 